\title{
Racial Politics and Sexual Violence in Post-Apartheid Contemporary South Africa in John Maxwell Coetzee's Disgrace (2000)
}

\section{Babacar Diakhaté}

Laboratoire d'Études africaines et postcoloniales, Université Cheikh Anta Diop, Dakar, Sénégal Email: diakhatebabacar83@hotmail.fr

\section{Abstract:}

The abolition of apartheid does not necessarily mean the resolution of social, political, racial and ethnic questions prevailing in South Africa. In Disgrace (2000), John Maxwell Coetzee depicts racial politics and gender, Sexism, social marginalization and alienation in South Africa. The aim of this article is to pinpoint sexual harassment and black females' abuse by the whites in Post-Apartheid South Africa. It shows whether sexual violence such as rape happens more in black South Africa than in the white community.

Keywords :

apartheid; sexism; race; violence; gender.

\section{Introduction}

For Many years, South Africans have suffered from the evil of Apartheid and people from different social classes such as the political activist, Nelson Mandela, the Anglican Bishops Desmond Tutu, the Novel Price literature Nadine Gordimer to name nut a few, all devote their lives to fight for equal human rights for all South Africans. Their commitment to improve the socio-political and racial conditions of their citizens is fruitful, hence the official abolition of Apartheid in 1994. However, in 2000 John Maxwell Coetzee releases Disgrace in which he castigates racial politics, sexism and discrimination in Post-Apartheid South Africa. The aim of this paper is first to examine how black females live harassment and victimization scenario in contemporary South Africa. It also focuses on Power or authority abuse in relation to gender. The final section shows the representation of rape and the silence of the victims.

\section{Review of Literature}

\section{Harassment and the Abuse of Black Females}

The abolition of Apartheid in South Africa in 1994 leaves its sequels in this rain-bow cultural nation. In Disgrace (2000), John Maxwell Coetzee denounces the racial and sexist system prevailing in contemporary South Africa. Coetzee presents, David Lurie, a fifty-two-year old white professor of Cape Town University, twice divorced with a single adult daughter known as Lucy. David is obsessed with having sex with any woman, even with his own students. Byron and the Prostitute Soraya are among David Lurie's whom he weekly encounters to satisfy his sexual desires. David's sexual intercourse with Melanie Isaac, a student with thirty years younger than him is the final straw that breaks the camel's back. As the matter of fact, Professor Lurie harasses his young black female student when he appreciates her beauty and slim shape saying that beauty does not belong to her alone (Coetzee, 2000). Coetzee informs readers of David's next sexual prey as he puts: Melanie Isaac, "the Dark one" (Coetzee, 2000). His reputation in the Technical University of Cape Town is smeared on for being a womanizer He does not like women who make no effort to be attractive (Coetzee, 2000). Professor David becomes obsessed with Melanie and they covertly live their love and intercourse. Melanie's young age pushes critics to say that David's intercourse with her can be judged as rape act. The "disciplinary committee" of Cape Town University does not see Melanie 
as a victim just because she is black. Readers are made by Coetzee to believe that David does not rape black Melanie. During the disciplinary Panel's audition, David comments on Melanie's lack of resistance and repulse. Coetzee asks: "what was he thinking?" but why does she not resist, or why did she say no, not now", rather than no, never (Coetzee, 2000). Readers say that David Lurie's intercourse with black Melanie Isaac is legally and actually a rape triggered off by her own behavior. Carine M. Mardorossian, University of Buffalo, in her article "Rape and the Violence Representation, in J. M; Coetzee's Disgrace”, considers David's act as the right to fulfill his “desires". She puts:

His forcefulness is naturalized as expected and somewhat normal (after all, isn't he, as he states, the servant of Eros?) and to "intuitively" understand his allegiance to the right of desire (as opposed to a human right paradigm includes women's rights)" (Mardorossian, 2011).

Carine who examines the works of Elizabeth Anker, argues that Lurie's claims about the "rights of desires "in fact exhibit a certain wisdom that works to illumine critical limitations of human rights and available diagnoses that they offer (Elizabeth, 2008). This appeal of David Lurie to human rights to satisfy "desires" is just an excuse for him. According to Coetzee, human rights have failed to take into account sexual and other irrational manifestations of persons and natural desires.

However, Coetzee's efforts to find an excuse for Prof David is just related to racism and discrimination. In the narrative, the stress is not put on the victim who is a young black girl but rather on how to justify Lurie's innocence. Had Melanie been a white student and David Lurie a black Professor, this act would have undoubtedly been considered as rape. In Disgrace race relations, sexism, gender questions and discrimination in post-apartheid contemporary South Africa are at the core of the narrative and the binary opposition between black and white, male and female, young and old and liberal and conservative is just an illustration. Carine quotes Donadio who in turn evokes Nadine Gordimer:

There is not one black person who is a real human being... I find it difficult to believe, indeed more that difficult, having lived here all my life and being part of everything that has bappened bere, that the black family protect the rapist because he is one of them...If that's the only truth be could find in the post-apartheid South Africa, I regretted this very much for him (Donadio, 2009).

The above-mentioned African Critics and the South African writer Christopher Van Wyk all claim that Coetzee's Disgrace is a racist book, it cannot be disassociated with racial discrimination. Professor David Lurie's harassment and abuse of the black student must be considered as rape like the other evils that existed during Apartheid in South Africa with the stereotypes of a violent and racist society. Attridge admits that:

We have got to accept the rape of a white as a gesture of all the evil that we did in the past. That's a load of a bloody bullshit. That white women are going to accept to be raped as penance for what was done in the past? Jesus. It's an expression of a very morbid phenomenon, very morbid (Attridge, 2004).

Carine evokes history in the United States of America and in South Africa. In the 1970s, there was a "tough-on-crime" rape policy in America to protect white women against black men's assaults and rapes. In South Africa also since the abolition of death penalty, more black men were hanged for raping white women than white men who raped black women(Buhlungu, 2007). In 1970s in the United States black men were almost the rapists of the white women and similarly in South Africa in 1992 blacks were hanged for raping whites South African women. In contrast between 1998 and 2000 black females are victims of rape and white men are rapists. Beinart asserts: Rapes of white women by black men similarly garner a disproportionate amount of media attention, even though nine out of ten 
women who are rape in the country are black (Beinart, 2001). White women's rape report to the public and in the media is more frequent than when black women are raped by white men.

\section{Discussion}

\subsection{Power Relations and Consequences}

Sexism and racial politics in post-Apartheid South Africa occur in the professional field. The abuse of power and authority is part and parcel of evils perpetrated by white people in the black community. In Disgrace, Coetzee shows how Professor David Lurie uses his position, as a white Professor, to victimize Melanie. Coetzee brings to light a debatable issue about Teachersstudents' relationships. This teacher/ Pupil bond can be based on mutual respect, submissiveness and even "paternity". However, it is awkward to mingle this relation with extra-professional link such as love, violence and abuse. Coetzee puts.... As teachers we occupy position of power/. Perhaps a ban on mixing power relations with sexual relations (Coetzee, 2000). The disciplinary committee warns the teaching staff about their responsibilities towards their students. Despite his old age, David succeeds in wooing Melanie, his student. David has the power to have Melanie in his room grudgingly. Whenever David and Melanie meet secretly, the next days, Melanie is entitled to be missing and David is obliged to register her as present and gives her a good mark. Coetzee vouches that the next days she is not in class, an unfortunate absence, since it is the day of the mid-term test. When he fills in the register afterwards, he ticks her off as present and enters a mark of seventy (Coetzee, 2000).

Melanie skips classes whenever she wants without running the risk of being punished. Her respect for Professor David Lurie wades away. The myth that should have existed between Melanie and the fifty-two-year old professor has collapsed. Melanie does no longer know the position that Pr David occupies in her: if she is David's student, daughter or even her mistress. After their intercourse, David tells her: I am leaving now, I have classes to meet. Try to sleep again. I will be back at noon, then we can talk. Mistress? Daughter? (Coetzee, 2000). This has negative consequences in the rest of Melanie's career in the University. The level that she had before meeting covertly with David Lurie has collapsed.

David is an object of reprisals by Melanie's classmates among whom her boyfriend. David, unconsciously, separates Melanie from her boyfriend. The more Melanie and David meet covertly the wider the distance between Melanie and her boyfriend becomes. Melanie admits you have cut me off from everyone; you have made me bear your secret. I am no longer just a student (Coetzee, 2000). The threat that David receives in his office from Melanie's boyfriend pushes David to step backward. Melanie's boyfriend menaces: Are you Professor David? Melanie has told me about you that you fucked her." The chickens come home to roost (Coetzee, 2000). David's car is vandalized and broken by unknown students, presumably Melanie's classmates. Coetzee asserts:

His car parked in the street is vandalized. The tyres are deflated, glue is injected into the door locks, newspapers are posted over the windscreen, and the paintwork is scratched. The locks have to be replaced; and the bill comes to six bundred rand.

Additionally, the consequences of Teacher/student sexual relationships are very devastating. Indeed, David's reputation is dragged in the mud by the 'buzz talk' around the University. The racial and sexual harassment of which Melanie is a victim reveals that Professor David is used to harassing other female students. Melanie asks him Have you slept with Amanda? (Coetzee, 2000).Melanie's abuse by David has a "buzz talk" effect thanks to the black color of her skin. 
Melanie no longer respects Lurie. When she wants to stop classes, her parents report this resignation to David to convince Melanie to continue her studies. David owns up: Respect! Your daughter lost respect for me weeks ago, and with good reasons. I'll see what I can do... I am the worm in the apple. How can I help you when I am the very source of your woe? (Coetzee, 2000).

David's meeting covertly with Melanie reduces class attendance. Students no longer attend his class. The docile and passive students are the only ones who attend classes. The students ask, if the professors who are role models in universities abuse the girls, who in this world must one trust then? The students' parents complain about this lack of morality. Coetzee reveals that:

We put our children in the hands of you people because we think we can trust you. If we can't trust the University, who can we trust? We never thought we were sending our daughter into a nest of vipers. No Professor Lurie, you may be high and mighty and have all kinds of degree, but if I was you, I'd be very ashamed of myself, so belp me God. If I've got of the wrong end of the stick, now is your chance to say, but I don't think so, I can see it from your face (Coetzee, 2000)

Racial discrimination and sexism are the evils that impede the black community to live adequately in South Africa. Mr Isaac, Melanie's father gives David the good lesson of his life. Mr Isaac lodges a complaint against Pr David for harassment and abuse of power or authority. Coetzee moralizes: Two names on the page, his and hers, side by side. Two in bed, lovers no longer but foes (Coetzee, 2000). David has fallen from grace to grass. Professor David had a well-ordered life in Cape Town by promoting knowledge, with summer heat, late afternoon tea, provincial gossip, the women sit in a circle and men play dreary Faro. Surprisingly, professor lands in Eastern Cape to take care of animals.

\subsection{Rape and Silence}

In Post-Apartheid South Africa women suffer much from gender and racial discrimination. The lack of jobs leads young South Africans to get indulge in prostitution and assaulting. After David's disgrace in Cape Town, he moves to Eastern Cape to live with her daughter on her Grahams town farm where three black boys attack them. Despite David's resistance, the black boys succeed in burning the farm and gang-raping Lucy. Lurie explains this brutal attack: they see me as owning something. They see themselves as debt collectors, tax collectors. Why should I be allowed to live here without paying? Perhaps that is what they tell themselves (Coetzee, 2000). Lucy's assault and physical abuse can't be disassociated with racism, gender and ethnicity. James Wood makes a close link between Melanie's and Lucy's rapes respectively by a white man and black boys. The narrative insists on the necessity of Lucy's "punishment" for her father committing a virtual a rape against Melanie (Wood, 2001). Wood states that Coetzee makes a parallel between David's 'disgrace' after raping Melanie and Lucy's 'disgrace'. According to Wood, Lucy is paying back the debt of rape and humiliation perpetrated by her own father. Johanna Stolarek, in exploring James Wood's works on Disgrace, shows that Lucy and her father are different but they share and undergo their different-but-similarforms of disgrace. Hence, the novels title reflects and powerfully demonstrates the essence of those two experiences, liking them in one mighty theme: disgrace (Wood, 2001).

Melanie's rape and Lucy's rape are distinct from perspective. Melanie is raped by a white person she knows, her professor. Whereas Lucy is violently and brutally gang raped by two black men and she becomes pregnant. David does not understand the reasons for Lucy's refusal to report rape to the police. Many readers think that since Lucy's rapists are young black men, reporting the rape is a symbol of humiliation and disgrace. Coetzee asks do you hope you can expiate the crimes in the past by suffering in the present." (Coetzee, 2000). In Disgrace, women such as, Lucy, Soraya, Melanie and Bev Shaw are deeply absorbed in an everlasting silence. None of them reveals 
to the public the hardships of life in Post-Apartheid South Africa. The resignation of Lucy to report and represent her rape is what Nancy Amstrong theories as "Violence of Representation". The aforementioned women are subjected to humiliation, rape and degradation. They suffer from excruciating situations of silence. The more they are silent, the more they expose themselves. This "Violence of Representation" encourages others to exploit them. Syed Manzoorul Islam states:

Soraya remains silent and passive during their sexual intercourse. Like Soray a Melanie also remains silent for few days against Lurie sexual harassment. Another Protagonist Lucy also remains silent after the barbaric occurrence: rape. She completely closes herself off from the world after the rape incident (Manzoorul Islam, 2015).

\section{Conclusion}

John Maxwell Coetzee's Disgrace examines the social, political, racial and cultural facets of Post-Apartheid South Africa. Coetzee underlines the critical attention paid to blacks on whites' sexual violence in South Africa. He succeeds in displaying how blacks are abused and harassed by whites who in turn accuse black men of "gang rapists". Therefore Disgrace tries to give answers about whether rape, sexism and discrimination occur only in black South Africa or in the whites too, in the context of Post-Apartheid South Africa.

\section{References}

Anker, E. (2008). “Human Rights, Social Justice, in J.M. Coetzee's Disgrace," Modern Fiction Studies 54.2:233-66. Print.

Amstrong, Nancy, and Tennenhouse L. (1989). "Introduction: Representing Violence' or 'How the West was Won". The Violence of Representation: Literature and the History of Violence. Ed. London: Routledge. 1-29. Print.

Attridge, D. (2004). J. M. Coetzee and the Ethics of Reading. Literature in Event. Chicago: U of Chicago. Beinart, W. (2001). Twentieth-Century South Africa.Oxford: Oxford UP.

Buhlungu, S., Daniel, J., Southal, R., Lutchman, J. (2007). State of the Nation: South Africa. Cape Town: Human Science Research Council.

Coetzee, M. J. (2000). Disgrace. Penguin Books.

Donadio, R. (2007). "Out of South Africa." The New york Time Sunday Book Review 16 Dec. 2007: 1-2; 19 Jan. 2009. http.//www.nytimes.com/2007/12/16/Books/Review/Donadiot.html?emc $=$ etal.

Graham, L., V. (2003). "Reading the Unspeakable: Rape in J. M. Coetzee's Disgrace.” Journal of Southern African Studies 29; 2: 433-444;

Islam, S., M. (2015). 'Presentation and Representation of Women in J. M. Coetzee's Disgrace”, English and Humanities Department BRAC University.

Mardorossian, M., C. (2011), Rape and the Violence of Representation in John Maxwell Coetzee's Disgrace, Research In African Literatures. Vol.42.N 4.University at Buffalo,

Reading in the Dark and Disgrace: The Representation of Oppression (http://www.fflchusp. $\mathrm{Br} / \mathrm{dlm} /$ yawp/yawp4/reading the dark.pdf).

Stolarek, J. (2015). "Political, Social and Cultural Aspects of Racism in Post-Apartheid South Africa in John Maxwell Coetzee's Disgrace" Siedlce University of Natural Science and Humanities, Poland.

Wood, J. (2001). 'Parables and Prices'. Available from http://www.Powells.Com/Review/. 